\title{
Total Phenolic, Flavonoids, Tannin Content and Antioxidant Power of Some Iranian Pomegranate Flower Cultivars (Punica granatum L.) ${ }^{*}$
}

\author{
Mannan Hajimahmoodi ${ }^{1,2 \#}$, Ghazaleh Moghaddam ${ }^{1}$, Ali Mohammad Ranjbar ${ }^{1}$, Hossein Khazani ${ }^{3}$, \\ Naficeh Sadeghi ${ }^{1}$, Mohammad Reza Oveisi ${ }^{1}$, Behrooz Jannat ${ }^{4}$
}

${ }^{1}$ Department of Drug and Food Control, Faculty of Pharmacy, Tehran University of Medical Sciences, Tehran, Iran; ${ }^{2}$ Department of Traditional, Faculty of Traditional Medicine, Tehran University of Medical Sciences, Tehran, Iran; ${ }^{3}$ Department of Biology, Tarbiat Moalem University, Tehran, Iran; ${ }^{4}$ Ministry of Health and Medical Education, Research Center, Tehran, Iran.

Email: "hajimah@tums.ac.ir

Received July $10^{\text {th }}, 2013$; revised August $10^{\text {th }}, 2013$; accepted August $25^{\text {th }}, 2013$

Copyright (C) 2013 Mannan Hajimahmoodi et al. This is an open access article distributed under the Creative Commons Attribution License, which permits unrestricted use, distribution, and reproduction in any medium, provided the original work is properly cited.

\begin{abstract}
Recently, pomegranate (Punica granatum L.) was demonstrated to be high in antioxidant activity and strong in phenolic, flavonoid and tannin contents in its fruit, flower and also aerial part. In this paper six cultivars of Iranian pomegranate flower including Ghojagh, Rabbab, Malas, Shishegap, Danesiah and Golnar have been investigated. The maximum amount of total phenolic was detected in Ghojagh $\left(25.94 \mathrm{mg} \cdot \mathrm{GAEg}^{-1}\right)$ and flavonoid showed the highest content in Danesiah $\left(23.06 \mathrm{mg} \cdot \mathrm{CEg}^{-1}\right)$. The lowest content of these two groups was observed in Golnar $\left(15.19 \mathrm{mg} \cdot \mathrm{GAEg}^{-1}\right.$ and $\left.11.46 \mathrm{mg} \cdot \mathrm{CEg}^{-1}\right)$. Measurement of tannin compounds showed that Rabbab by $2.03 \%$ and Golnar by $1.06 \%$ have the highest and lowest amount respectively. According to the FRAP method, Ghojagh and Golnar have the highest and lowest antioxidant values respectively $\left(452.53 \mathrm{mmol} \cdot \mathrm{g}^{-1}\right.$ and $\left.123.39 \mathrm{mmol} \cdot \mathrm{g}^{-1}\right)$. As a result of HPLC-DPPH method, Malas and Danesiah have the highest and lowest antioxidant value $\left(116.38\right.$ and $\left.97.64 \mathrm{mgVEEg}^{-1}\right)$.
\end{abstract}

Keywords: Pomegranate; Flower; Antioxidant; Phenolic; HPLC

\section{Introduction}

Pomegranate (Punica granatum L.) which is widely cultivated in Iran has been popular worldwide over the years originated from Middle East and Iran [1,2]. The pomegranate fruit has been commercialized and can be found as juice, jellies, wine. The wide adoption of the pomegranate is due to the recent studies that mentioned it that contains a high amount of antioxidants which are beneficial to our health in many ways [3-6]. Its great flavor and health benefits have made it a great candidate for those who search natural healthy foods [7]. Pomegranate is an important source of bioactive compounds and different parts of it have been used in medicine for many centuries $[3,8]$ and the edible parts used pharmaceutically worldwide. In tradition medicine, the pricarp was used by Chinese for the treatment of diarrhea, metrorrhagia, metrostaxis and bellyache. The flower was used as a flower

${ }^{*}$ The authors declare that they have no conflict of interests.

\#Corresponding author. supplement to treat diabetes mellitus in Unani medicine and the diarrhea was treatment by pomegranate fruit in South Africa [9]. Pomegranate juice has been demonstrated to be high in antioxidant activity and is effective in the prevention of atherosclerosis, coronary heart disease and cancer $[4,10]$. There are some reports about the presence of tannins, alkaloids, glycosides, flavonoids and phenolic compounds as antioxidant factors in juice, peel, pulp, and seed fractions of pomegranate [11-13]. In the case of flower, the pomegranate flowers had a medicinal use in Traditional Iranian Medicine and also in the current studies $[14,15]$. In folk medicine the decoction of flowers is used to stop bleeding and purging $[16,17]$. Pomegranate flowers (golnar) contain a variety of secondary metabolites such as poly phenols with strong antioxidant activity [18]. The polyphenols in pomegranate flowers have ellagic acid which had a marked inhibitory effect on the occurrence and development of tumours in mice [19]; triterpenes show antimutagenic and anticarcinogenic effects [20]; and oleanolic acid significantly 
enhanced acute glucose-stimulated insulin secretion at basal and stimulatory glucose concentrations inpancreatic b-cell. Such effects may contribute to the antidiabetic properties [21]. The bright colour of pomegranate flowers and arils is due to anthocyanins [22]; however, only one anthocyanin compound (i.e. pelargonidin-3,5-diglucoside) has yet been identified in pomegranate flowers using HPLC [23], whereas in pomegranate juice, princepally cyanidin-3-O-glucoside, cyanidin-3,5-di-O-glucoside, delphinidin-3-O-glucoside, delphinidin-3,5-di-O-glucoside, pelargonidin-3-O-glucoside, and pelargonidin-3,5-di-Oglucoside, have been reported [24, 25]. Oleanolic acid, ursolic acid and gallic acid, active components contained in pomegranate flower [26], have long been recognized to have antihyperlipidemic properties [27,28]. It is known that the amount of organic acids, phenolic compounds, sugars, water-soluble vitamins, and minerals of all parts of pomegranates are different in various researches which may be attributed to their cultivar origins $[29,30]$.

Therefore, in this study, the contents of total phenolic, flavonoids, and tannins of the some Iranian pomegranate flower cultivars and their antioxidant activity were investigated through the FRAP and HPLC-DPPH methods.

\section{Materials and Methods}

\subsection{Sample Preparation}

Six cultivars of pomegranate's flower were obtained from Agricultural Research Center, Yazd, Iran. The flowers varieties (Malas, Shishegap, Danesiah, Rabbab, Ghojagh and Golnar) were harvested during May 2012 from different mature trees which randomly selected. Flowers were desiccated in shade and room temperature. Then, different flower cultivars were grounded separately by mortar. $0.5 \mathrm{~g}$ of each cultivar was shaken with methanol $80 \%$ for 2 hours and centrifuged in 10,000 rpm [HereusGermany] then the extracts were separated and stored in $4^{\circ} \mathrm{C}[9]$.

According to the tannin determination, $3 \mathrm{~g}$ of each dried flower powder was extracted with deionized distilled water in $250 \mathrm{~mL}$ volumetric flask during 4 hours at room temperature and then the sample was filtered [31].

\subsection{Total Phenolic Content}

Total phenolics contents were determined according to the Folin-Ciocalteu method with slight modifications [32]. The extract $(200 \mu \mathrm{L})$ was mixed with $1.5 \mathrm{~mL}$ of Folin-Ciocalteu reagent [previously diluted 10 times with double distilled water] and allowed to stand at room temperature for $5 \mathrm{~min}$. $1.5 \mathrm{~mL}$ sodium bicarbonate solution [60 $\left.\mathrm{g} \cdot \mathrm{L}^{-1}\right]$ was added to the mixture and after incubation for $90 \mathrm{~min}$ at room temperature, the absorbance level was measured at $725 \mathrm{~nm}$ using a UV-Visible spectropho- tometer (GBC, Cintra 40). Total phenolic were quantified by calibration curve obtained from measuring the absorbance of the known concentrations of gallic acid standard solutions $\left[10-150 \mu \mathrm{g} \cdot \mathrm{mL}^{-1}\right.$ in $80 \%$ methanol]. The results were calculated as gallic acid equivalent (GAE) per one gram dry powder and reported as mean value \pm standard deviation (SD).

\subsection{Total Flavonoid Content}

Total flavonoid content was measured by the aluminum chloride colorimetric method [33]. An aliquot (1 mL) of each extract was added to $10 \mathrm{~mL}$ volumetric flask containing $4 \mathrm{~mL}$ of double distilled water. Then $0.3 \mathrm{~mL}$ $\mathrm{NaNO}_{2} 5 \%$ was added to the flask and after $5 \mathrm{~min}, 0.3$ $\mathrm{mL} \mathrm{AlCl}_{3}$ [10\%] was also added. At 6th $\mathrm{min}, 2 \mathrm{~mL}$ $\mathrm{NaOH}(1 \mathrm{M})$ was added and the total volume was made up to $10 \mathrm{~mL}$ with double distilled water. The solution was mixed completely and the absorbance level was measured versus prepared reagent blank at $510 \mathrm{~nm}$. Total flavonoid content was expressed as $\mathrm{mg}$ catechin equivalents (CE) per one gram dry powder. The total flavonoid assay was measured three times for each pomegranate extract. $1 \mathrm{~mL}$ of standard solution (catechin: $5-100 \mathrm{mg}$ / L) was used to construct calibration curve.

\subsection{Antioxidant Assay (FRAP Method)}

The FRAP (Ferric reducing antioxidant power) assay was described initially by Benzie and Strain [34]. The principle of this method is based on the reduction of the ferrictripyridyl triazine complex to its ferrous colored form in the presence of antioxidants. Briefly, the FRAP reagent contained $5 \mathrm{~mL}$ TPTZ (2,4,6-tripyridyl-S-triazine, 10 $\mathrm{mmol} \cdot \mathrm{L}^{-1}$ ) solution in $40 \mathrm{mmol} \cdot \mathrm{L}^{-1} \mathrm{HCl}$ plus $5 \mathrm{~mL} \mathrm{FeCl}{ }_{3}$ $\left[20 \mathrm{~mol} \cdot \mathrm{L}^{-1}\right]$ and $50 \mathrm{~mL}$ of Acetate buffer $\left(0.3 \mathrm{~mol} \cdot \mathrm{L}^{-1}\right)$. It was prepared freshly and set at $37^{\circ} \mathrm{C}$. Aliquots of 50 $\mu \mathrm{L}$ sample supernatant were mixed with $1.5 \mathrm{~mL}$ FRAP reagent and the absorbance of reaction mixture at $593 \mathrm{~nm}$ was measured spectrophotometrically after incubation at $37^{\circ} \mathrm{C}$ for $10 \mathrm{~min}$. To construct the calibration curve five concentrations of $\mathrm{FeSO}_{4} \cdot 7 \mathrm{H}_{2} \mathrm{O}\left(100-1000 \mathrm{mmol} \cdot \mathrm{L}^{-1}\right)$ were used and the absorbencies were measured as sample solution. The values were expressed as the concentration of antioxidants having a ferric reducing ability equivalent to that of $1 \mathrm{mmol} \cdot \mathrm{L}^{-1} \mathrm{FeSO}_{4}$. All the measurements were taken in triplicate and expressed as mean value \pm RSD.

\subsection{Antioxidant Assay [HPLC-DPPH Method]}

The chromatographic analysis was carried out by a Knauer HPLC system [Berlin, Germany] equipped with an auto-sampler, pump and a UV-Vis detector. $20 \mu \mathrm{L}$ of each samples $(1 \mathrm{~mL}$ extract was volumed to $5 \mathrm{~mL}$ with methanol $80 \%$ in volumetric flask) was added to $2 \mathrm{~mL}$ 
1,1-diphenyl-2-picrylhydrazyl [DPPH] solution at a concentration of $0.1 \mathrm{mmol} \cdot \mathrm{L}^{-1}$ and mixed with $20 \mathrm{~mL}$ deionized distilled water. Trolox $\left(1 \mathrm{mg} \cdot \mathrm{mL}^{-1}\right)$ and deionized distilled water were used as the standard of vitamin $\mathrm{E}$ and blank respectively and were prepared by adding 20 $\mu \mathrm{L}$ of each one to $2 \mathrm{~mL}$ DPPH solution. The mixture was shacked 20 seconds and then kept in the darkness $40 \mathrm{~min}$ at room temperature. $20 \mu \mathrm{L}$ of prepared samples which were filtered through $0.2 \mu \mathrm{m}$ membrane filter [Control Biogen-Spain] was injected to the HPLC. The radical scavenging activity of DPPH was measured at $517 \mathrm{~nm}$. All samples were analyzed in triplicate (mean \pm RSD) [35].

\subsection{Tannin Assay}

The analyses of tannin content in flowers were performed according to the International Pharmacopoeia and AOAC methods [36] with some modifications. $3 \mathrm{~g}$ of flower powder was infused with $250 \mathrm{~mL}$ of deionized double distilled water and then it was filtered through $0.45 \mu \mathrm{m}$ (Control Biogen-Spain) sample filter. $25 \mathrm{~mL}$ of the infusion was added into $1 \mathrm{~L}$ conical flask and then 25 $\mathrm{mL}$ of indigo solution $[0.6 \%]$ and $750 \mathrm{~mL}$ deionized distilled water was added. The solution has been titrated with $0.1 \mathrm{~N}$ aqueous solution of $\mathrm{KMNO}_{4}$ until the blue colored solution changed to golden yellow one. Standard solution of indigo carmine was prepared as following: 6 $\mathrm{g}$ indigo carmine was dissolved in $500 \mathrm{~mL}$ of deionized distilled water by heating and after cooling $50 \mathrm{~mL}$ of $98 \% \mathrm{H}_{2} \mathrm{SO}_{4}$ was added. The solution was diluted to $1 \mathrm{~L}$ with deionized distilled water and then it was filtered through $0.2 \mu \mathrm{m}$ membrane filter. The blank test was carried out by titration of the mixture of $25 \mathrm{~mL}$ indigo carmine and $775 \mathrm{~mL}$ double distilled water. All samples were analyzed in duplicates. The tannin percent [\%] in the samples were calculated as follows:

$$
\mathrm{T}(\%)=\left[\mathrm{V}-\mathrm{V}_{0}\right] 0.004157 \times 250 \times 100 / \mathrm{g} \times 25
$$

where $\mathrm{V}$ is the volume of $0.1 \mathrm{~N}$ aqueous solution of $\mathrm{KMNO}_{4}$ used in the titration of the sample and $\mathrm{V}_{0}$ is the volume of $0.1 \mathrm{~N}$ aqueous solution of $\mathrm{KMNO}_{4}$ used in the titration of the blank sample as $\mathrm{mL} ; 0.004157$ is the tannins equivalent in $1 \mathrm{~mL}$ of $0.1 \mathrm{~N}$ aqueous solution of $\mathrm{KMNO}_{4}$; $\mathrm{g}$ is the mass of the sample taken for the analysis as gram and 250 is the volume of the volumetric flask.

\subsection{Statistical Analysis}

Three replicates of each sample were used for statistical analysis and the values were reported as mean \pm RSD. Pearson's correlation was carried out using SPSS statistical program to study the relationship between antioxidant activity and total phenolic and flavonoid content. Data were also subjected to the analysis of variance and mean values were compared by Tukey post-hoc multiomparison test. Differences at $\mathrm{p}$-value $<0.05$ were considered to be significant.

\section{Results and Discussion}

Pomegranate flower has been used in traditional Iranian medicine according to its medicinal effects [14]. The total phenolic content of pomegranate flower extracts is expressed in term of gallic acid equivalent (the standard curve equation: $\left.\mathrm{Y}=0.005 \mathrm{X}-0.0234, \mathrm{r}^{2}=0.9975\right)$. It was ranged from $25.94 \%$ to $15.19 \% \mathrm{mg}$ gallic acid equivalents per gram of dry powder in Ghojagh and Golnar respectively (Table 1). The total flavonoid content of flower extracts is also expressed in terms of catechin equivalent (the standard curve equation: $\mathrm{y}=0.005 \mathrm{x}+$ $0.1478, r^{2}=0.9919$ ), ranged from $23.06 \%$ to $11.46 \% \mathrm{mg}$ catechin equivalents per gram of dry flower powder in Danesiah and Golnar respectively (Table 1).

Phenolic and flavonoid contents are important in antioxidant power of herbals and the analysis of their amount in different pomegranate flower cultivars via ANOVA shows that Ghojagh has the most amount of total phenol and Golnar has the least ones ( $p$-value $<0.05$ ). In the case of total flavonoid, Danesiah cultivar has the most content $\left(23.06 \mathrm{mgCE} \cdot \mathrm{g}^{-1}\right)$ and Golnar cultivar has the

Table 1. The total phenolic, flavonoid, tannin content and flavonoid-phenolic ratio of six pomegranate flower cultivars.

\begin{tabular}{ccccc}
\hline Cultivar & $\begin{array}{c}\text { Total phenol } \\
\text { [mg GAE/g dry powder } \pm \text { RSD] }\end{array}$ & $\begin{array}{c}\text { Total flavonoid } \\
\text { [mg CE/g dry powder } \pm \text { RSD] }\end{array}$ & $\begin{array}{c}\text { Total tannin } \\
\text { [\% } \pm \text { RSD] }\end{array}$ & Flavonoid/Phenolic \\
\hline Ghojagh & $25.94^{\mathrm{a}} \pm 7.00$ & $19.17^{\mathrm{b}} \pm 4.31$ & $1.33^{\mathrm{b}} \pm 0.22$ & $0.74^{\mathrm{c}}$ \\
Rabbab & $24.57^{\mathrm{a}} \pm 5.04$ & $16.76^{\mathrm{c}} \pm 2.17$ & $2.03^{\mathrm{a}} \pm 0.15$ & $0.68^{\mathrm{c}}$ \\
Shishegap & $20.60^{\mathrm{b}} \pm 6.21$ & $18.30^{\mathrm{b}} \pm 2.32$ & $1.29^{\mathrm{b}} \pm 0.43$ & $0.89^{\mathrm{b}}$ \\
Danesiah & $23.48^{\mathrm{a}} \pm 4.46$ & $23.06^{\mathrm{a}} \pm 3.46$ & $1.98^{\mathrm{a}} \pm 0.67$ & $0.98^{\mathrm{a}}$ \\
Malas & $18.68^{\mathrm{c}} \pm 3.01$ & $18.21^{\mathrm{b}} \pm 4.49$ & $1.47^{\mathrm{b}} \pm 04$ & $0.97^{\mathrm{a}}$ \\
Golnar & $15.19^{\mathrm{d}} \pm 2.02$ & $11.46^{\mathrm{d}} \pm 2.17$ & $1.06^{\mathrm{c}} \pm 0.11$ & $0.75^{\mathrm{c}}$ \\
\hline
\end{tabular}

Values in the same column bearing different superscripts are significantly $(\mathrm{p} \leq 0.05)$ different. 
Table 2. Antioxidant power of six pomegranate flower cultivar according to the FRAP and HPLC-DPPH method.

\begin{tabular}{ccc}
\hline Cultivar & $\mathbf{m m o l ~ F e}^{2+}$ equivalent/g dry powder \pm RSD & Mg vitamin E equivalent/g of dry powder \pm RSD \\
\hline Ghojagh & $452.53^{\mathrm{a}} \pm 25.08$ & $109.93^{\mathrm{b}} \pm 20.60$ \\
Rabbab & $219.77^{\mathrm{c}} \pm 19.87$ & $112.13^{\mathrm{a}} \pm 14.40$ \\
Shishegap & $219.05^{\mathrm{c}} \pm 13.18$ & $109.68^{\mathrm{b}} \pm 16.48$ \\
Danesiah & $200.33^{\mathrm{c}} \pm 21.44$ & $97.64^{\mathrm{c}} \pm 16.69$ \\
Malas & $337.04^{\mathrm{b}} \pm 15.45$ & $116.38^{\mathrm{a}} \pm 20.81$ \\
Golnar & $123.39^{\mathrm{d}} \pm 17.38$ & $107.63^{\mathrm{b}} \pm 21.02$ \\
\hline
\end{tabular}

Values in the same column bearing different superscripts are significantly $(\mathrm{p} \leq 0.05)$ different.

least content $\left(11.46 \mathrm{mgCE} \cdot \mathrm{g}^{-1}\right)$ significantly. Analysis of antioxidant power according to the FRAP method show Ghojagh $\left(452.53 \mathrm{mmol} \mathrm{Fe} \mathrm{F}^{2+} \cdot \mathrm{g}^{-1}\right)$ has the most antioxidant power while Golnar $\left(123.39 \mathrm{mmol} \mathrm{Fe}{ }^{2+} \cdot \mathrm{g}^{-1}\right)$ has the least ones. By the HPLC-DPPH method Malas (116.38 $\mathrm{mgVitEE}^{-1}$ ) have the most antioxidant effect and Danesiah $\left(97.64 \mathrm{mgVitEE}^{-1}\right)$ has the least antioxidant power (Table 2). The Pearson's correlation showed no significant correlation between total phenolic and flavonoid content and antioxidant power via both FRAP and HPLCDPPH methods. The total tannin content in different cultivars were also compared according to the statistical calculation and the results showed Rabbab and Danesiah cultivars have the highest amount of tannin and Golnar has the least content. The flavonoid-phenolic ratio in Table 1 is mentioned to show the importance of flavonoids in total phenolic content and its antioxidant activity. The range of this ratio is between 0.98 in Danesiah and 0.68 in Rabbab.

In a prosperous in vitro and also in vivo study by Kaur et al. [15] the pomegranate flower extract indicated a significant antioxidant activity and it was found to exhibit a potent protective role in acute oxidative tissue injury animal in vivo model. Also the ethanolic extract of pomegranate flower showed $81.6 \%$ antioxidant activity in DPPH model system.

Comparison of the pomegranate flower results with its pulp and peel [37] showed flowers have higher amount of the total phenol and flavonoids content, but it has less antioxidant activity according to the FRAP method. It can be suggested that water soluble antioxidant such as organic acid can leads to antioxidant activity of pulp and water insoluble component to the flower. In another study the antioxidant activity and total phenolic content of pomegranate flower and juice were compared and in spite of higher amounts of phenolic compounds in flower extracts, antioxidant activity of juices were more than flowers indicating results as the same as this study [38]. Total phenolic and flavonoid content of peel and its antioxidant activity in another research is remarkable more than the flower and suggest the peel as a better source of antioxidant components [37]. In Orak et al. study [39], the DPPH scavenging activity of antioxidant in juice, peel, and seed parts of pomegranate were investigated. The results showed that the $\mathrm{EC}_{50}$ value of DPPH scavenging activities in peel extracts was 23.4-fold higher than the juice extracts, and the seed extracts had 2.3-fold higher than juice. Also the reducing power in peel extracts was found to be 4.7-fold higher than seed extracts and 10.5-fold higher than the juice. The data expressed that, in peel and pulp except that, the total polyphenol and tannin contents, flavonoid and anthocyanin play an important role in antioxidant activity respectively.

\section{Conclusion}

The antioxidants assessment suggests that the studied pomegranate flower and its associated bioactive compounds such as phenolic, flavonoids and tannins compounds may possess a strong potential as a chemo preventive and possibly as new tools for preventing various human diseases. However, further studies should focus on developing the novel pomegranate derived products such as ready-to-eat pomegranate flower, single-strength juices, flower extract concentrates, flower in syrup, and the frozen flower, to benefit from these constituents throughout a healthy life cycle.

\section{Acknowledgements}

This work was student thesis and supported by the grant from the research council of Tehran University of Medical Sciences, Tehran, Iran.

\section{REFERENCES}

[1] S. Y. Schubert, E. P. Lansky and I. Neeman, "Antioxidant and Eicosanoid Enzyme Inhibition Properties of Pomegranate Seed Oil and Fermented Juice Flavonoids," Journal of Ethnopharmacology, Vol. 66, No. 1, 1999, pp. 1117. doi:10.1016/S0378-8741(98)00222-0 
[2] M. Khanavi, G. Moghaddam, M. R. Oveisi, N. Sadeghi, B. Jannat, M. Rostami, M. A. Saadat and M. Hajimahmoodi, "Hyperoside and Anthocyanin Content of Ten Different Pomegranate Cultivars," Pakistan Journal of Biological Sciences, Vol. 16, No. 13, 2013, pp. 636-641. doi:10.3923/pjbs.2013.636.641

[3] M. Hajimahmoodi, M. R. Oveisi, N. Sadeghi, B. Jannat, M. Hadjibabaie, E. Farahani, M. R. Akrami and R. Namdar, "Antioxidant Properties of Peel and Pulp Hydro Extract in Ten Persian Pomegranate Cultivars," Pakistan Journal of Biological Sciences, Vol. 11, No. 12, 2008, pp. 1600-1604. doi:10.3923/pjbs.2008.1600.1604

[4] B. Fuhrman, N. Volkova and M. Aviram, "Pomegranate Juice Inhibits Oxidized LDL Uptake and Cholesterol Biosynthesis in Macrophages," The Journal of Nutritional Biochemistry, Vol. 16, No. 9, 2005, pp. 570-576. doi:10.1016/j.jnutbio.2005.02.009

[5] M. A. Jeune, J. Kumi-Diaka and J. Brown, “Anticancer Activities of Pomegranate Extracts and Genistein in $\mathrm{Hu}-$ man Breast Cancer Cells," Journal of Medicinal Food, Vol. 8, No. 4, 2005, pp. 469-475. doi:10.1089/jmf.2005.8.469

[6] A. R. Neurath, N. Strick, Y. Y. Li and A. K. Debnath, "Punica Granatum [Pomegranate] Juice Provides an HIV1 Entry Inhibitor and Candidate Topical Microbicide," BMC Infectious Diseases, Vol. 4, No. 41, 2004, pp. 311327.

[7] P. S. Negi, G. K. Jayaprakasha and B. S. Jena, "Antioxidant and Antimutagenic Activities of Pomegranate Peel Extracts," Food Chemistry, Vol. 80, No. 3, 2003, pp. 393397. doi:10.1016/S0308-8146(02)00279-0

[8] W. Elfalleh, H. Hannachi, N. Tlili, Y. Yahia, N. Nasri and A. Ferchichi1, "Total Phenolic Contents and Antioxidant Activities of Pomegranate Peel, Seed, Leaf and Flower," Journal of Medicinal Plants Research, Vol. 6, No. 1, 2012, pp. 4724-4730.

[9] N. Panchavarnakili, S. Tamil Selvi, D. Pavai, A. Panneerselvam and M. Prabakaran, "Antimicrobial Studies and Phytochemical Screening of Stem Bark in Syzigium cumini [L.] and Lannea coromentalica Houtt [Merr.]," Asian Journal of Plant Science \& Research, Vol. 2, No. 2, 2012, pp. 89-94.

[10] M. D. Sumner, M. Elliott-Eller, G. Weidner, J. J. Daubenmier, M. H. Chew, R. Marlin, C. J. Raisin and D. Ornish, "Effects of Pomegranate Juice Consumption on Myocardial Perfusion in Patients with Coronary Heart Disease," American Journal of Cardiology, Vol. 96, No. 6, 2005, pp. 810-814. doi:10.1016/j.amjcard.2005.05.026

[11] C. Guo, J. Yang, J. Wei, Y. Li, J. Xu and Y. Jiang, "Antioxidant Activities of Peel, Pulp and Seed Fractions of Common Fruits as Determined by FRAP Assay," Nutrition Research, Vol. 23, No. 12, 2003, pp. 1719-1726.

[12] N. P. Seeram, L. S. Adams, S. M. Henning, Y. Niu, Y. Zhang, M. G. Nair and D. Heber, "In Vitro Antiproliferative, Apoptotic and Antioxidant Activities of Punicalagin, Ellagic Acid and a Total Pomegranate Tannin Extract Are Enhanced in Combination with Other Polyphenols as Found in Pomegranate Juice," Journal of Nutritional Bio- chemistry, Vol. 16, No. 6, 2005, pp. 360-367. doi:10.1016/i.jnutbio.2005.01.006

[13] Y. Noda, T. Kaneyuki, A. Mori and L. Packer, "Antioxidant Activities of Pomegranate Fruit Extract and Its Anthocyanidins: Delphinidin, Cyanidin and Pelargonidin," Journal of Agricultural and Food Chemistry, Vol. 50, No. 1, 2002, pp. 166-171. doi:10.1021/jf0108765

[14] M. H. Aghili, "Makhzan-al-Advia," Tehran University of Medical Sciences, 2009.

http://aqlibrary.org/UserFiles/File/makhzan.pdf

[15] G. Kaur, Z. Jabbar, M. Athar and M. S. Alam, "Punica Granatum [Pomegranate] Flower Extract Possesses Potent Antioxidant Activity and Abrogates Fe-NTA Induced Hepatotoxicity in Mice," Food and Chemical Toxicology, Vol. 44, No. 7, 2006, pp. 984-993. doi:10.1016/j.fct.2005.12.001

[16] V. V. Sivarajan and I. Balachandran, "Ayurvedic Drugs and Their Plant Sources," Oxford and IBH Publishing Co. Pvt. Ltd., Delhi, 1994.

[17] M. A. Jafri, M. Aslam, K. Javed and S. Singh, "Effect of Punica granatum Linn. [Flowers] on Blood Glucose Level in Normal and Alloxan-Induced Diabetic Rats," Journal of Ethnopharmacology, Vol. 70, No. 3, 2000, pp. 309314. doi:10.1016/S0378-8741(99)00170-1

[18] T. Oswa, A. Ide, J. D. Su and M. Namiki, "Inhibiting of Lipid Peroxidation by Ellagic Acid," Journal of Agricultural and Food Chemistry, Vol. 35, No. 3, 1987, pp. 808812. doi:10.1021/jf00077a042

[19] M. Boukharta, G. Jalbert and A. Castonguay, "Efficacy of Ellagitannins and Ellagic Acid as Cancer Chemo Preventive Agents," Proceeding of International Conference of the Group Polyphenols, Lisbon, 13-16 July 1992, pp. 245-249.

[20] Z. Ovesna, A. Vachalkova, K. Horvathova and D. Tothova, "Pentacyclic Triterpenoic Acids: New Chemoprotective Compounds Minireview," Neoplasma, Vol. 51, No. 5, 2004, pp. 327-333.

[21] T. Teodoro, L. Zhang, T. Alexander, J. Yue, M. Vranic and A. Volchuk, "Oleanolic Acid Enhances Insulin Secretion in Pancreatic b-Cells," FEBS Letters, Vol. 582, No. 9, 2008, pp. 1375-1380. doi:10.1016/j.febslet.2008.03.026

[22] F. Afaq, M. Saleem, C. G. Krueger, J. D. Reed and H. Mukhtar, "Anthocyanin- and Hydrolyzable Tannin-Rich Pomegranate Fruit Extract Modulates Mapk and Nfkappab Pathways and Inhibits Skin Tumorigenesis in CD-1 Mice," International Journal of Cancer, Vol. 113, No. 3, 2005, pp. 423-333. doi:10.1002/ijc.20587

[23] M. G. Miguel, S. Dandlen and M. A. Neves, "Antioxidant Activities of Flower Extract and Pomegranate Juice," Acta Horticulturae, Vol. 8183, 2009, pp. 389-394.

[24] E. P. Lansky and R. A. Newman, "Punica granatum [Pomegranate] and Its Potential for Prevention and Treatment of Inflammation and Cancer," Journal of Ethnopharmacology, Vol. 109, No. 2, 2007, pp. 177-206. doi:10.1016/i.jep.2006.09.006

[25] V. Jaiswal, A. DerMarderosian and J. R. Porter, "Antho- 
cyanins and Polyphenol Oxidase from Dried Arils of Pomegranate [Punica granatum L.]," Food Chemistry, Vol. 118, 2010, pp. 11-16. doi:10.1016/j.foodchem.2009.01.095

[26] Y. Li, Y. Qi, T. H. W. Huang, J. Yamahara and B. D. Roufogalis, "Pomegranate Flower: A Unique Traditional Antidiabetic Medicine with Dual PPAR-Alpha/-Gamma Activator Properties," Diabetes, Obesity and Metabolism, Vol. 10, No. 1, 2008, pp. 10-17.

[27] J. Liu, "Pharmacology of Oleanolic Acid and Ursolic Acid," Journal of Ethnopharmacology, Vol. 49, No. 2, 1995, pp. 57-68. doi:10.1016/0378-8741(95)90032-2

[28] A. Jang, P. Srinivasan, N. Y. Lee, H. P. Song, J. W. Lee, M. Lee and C. Jo, "Comparison of Hypolipidemic Activity of Synthetic Gallic Acid-Linoleic Acid Ester with Mixture of Gallic Acid and Linoleic Acid, Gallic Acid and Linoleic Acid on Highfat Diet Induced Obesity in C57BL/6 Cr Slc Mice," Journal of Ethnopharmacology, Vol. 174, No. 2, 2008, pp. 109-117.

[29] M. H. Davidson, K. C. Maki, M. R. Dicklin, S. B. Feinstein, M. Witchger, M. Bell, D. K. McGuire, J. C. Provost, H. Liker and M. Aviram, "Effects of Consumption of Pomegranate Juice on Carotid Intima-Media Thickness in Men and Women at Moderate Risk for Coronary Heart Disease," American Journal of Cardiology, Vol. 104, 2009, pp. 936-942. doi:10.1016/j.amjcard.2009.05.037

[30] F. Tezcan, M. Gultekin-Ozguven, T. Diken, B. Ozcelik and F. B. Erim, "Antioxidant Activity and Total Phenolic, Organic Acid and Sugar Content in Commercial Pomegranate Juices," Food Chemistry, Vol. 115, 2009, pp. 873-877. doi:10.1016/j.foodchem.2008.12.103

[31] M. Tanassova and V. Christova-Bagdassarian, "Determination of Tannins Contents by Titrimetric Method for Comparison of Different Plant Spiceies," Journal of the University of Chemical Technology and Metallurgy, Vol. 44, No. 4, 2009, pp. 411-415.

[32] Y. S. Velioglu, G. Mazza, L. Gao and B. D. Oomah, "AnTioxidant Activity and Total Phenolics in Selected Fruits,
Vegetables and Grain Products," Journal of Agricultural and Food Chemistry, Vol. 46, No. 10, 1998, pp. 41134117. doi:10.1021/jf9801973

[33] J. Zhishen, T. Mengcheng and W. Jianming, "The Determination of Flavonoid Contents in Mulberry and Their Scavenging Effects on Superoxide Radicals," Food Chemistry, Vol. 64, No. 4, 1999, pp. 555-559. doi:10.1016/S0308-8146(98)00102-2

[34] I. F. F. Benzie and J. J. Strain, "The Ferric Reducing Ability of Plasma [FRAP] as a Measure of Antioxidant Power: The FRAP Assay," Analytical Biochemistry, Vol. 239, No. 1, 1996, pp. 70-76. doi:10.1006/abio.1996.0292

[35] T. Katsube, H. Tabata, Y. Ohta, Y. Yamasaki, E. Anuurad, K. Shiwaku and Y. Yamane, "Screening for Antioxidant Activity in Edible Plant Products: Comparison of LowDensity Lipoprotein Oxidation Assay, DPPH Radical Scavenging Assay and Folin-Ciocalteu Assay," Journal of Agricultural and Food Chemistry, Vol. 52, No. 8, 2004, pp. 2391-2396. doi:10.1021/jf035372g

[36] W. Horwitz and G. Latimer, "Official Methods of Analysis of AOAC International."

[37] M. R. Shams Ardekani, M. R. Oveisi, N. Sadeghi, B. Jannat, A. M. Ranjbar, N. Gholam and T. Moridi, "Comparative Antioxidant Activity and Total Flavonoid Content of Persian Pomegranate [Punica Granatum L.] Cultivars," Iranian Journal of Pharmaceutical Research, Vol. 10, No. 3, 2011, pp. 519-524.

[38] A. K. Batta and S. Rangaswami, "Crystalline Chemical Components of Some Vegetable Drugs," Phytochemistry, Vol. 12, 1973, pp. 214-216. doi:10.1016/S0031-9422(00)84654-3

[39] H. H. Orak, H. Yagar and S. S. Isbilir, "Comparison of Antioxidant Activities of Juice, Peel and Seed of Pomegranate [punica granatum 1.] and Inter-Relationships with Total Phenolic, Tannin, Anthocyanin and Flavonoid Contents," Food Science and Biotechnology, Vol. 21, No. 2, 2012, pp. 373-387. doi:10.1007/s10068-012-0049-6 